\title{
ORO-DENTAL CLINICAL ASPECTS IN CHILDREN WITH THALASSEMIA
}

\author{
Andrei KOZMA ${ }^{1}$, Florentina VLADAREANU ${ }^{2}$, Doriana AGOP-FORNA ${ }^{3}$, \\ Andreea D. IORDAN DUMITRU ${ }^{4}{ }^{\circledR}$, Claudiu TOPOLICEANU ${ }^{5}$
}

${ }^{1}$ „Alessandrescu - Rusescu“ National Institute for Mother and Child Health, Bucharest, Romania

2 „Prof. C.T. Nicolau“ National Institute of Transfusional Hematology, Bucharest, Romania

${ }^{3}$ Dental Medicine Faculty, "Grigore T. Popa" University of Medicine and Pharmacy, Iasi, Romania

${ }^{4}$ „Titu Maiorescu“ University, Faculty of Dental Medicine, Bucharest, Romania

${ }^{5}$ Dental Medicine Faculty, "Grigore T. Popa" University of Medicine and Pharmacy, Iasi, Romania

Received 10 Apr 2019, Accepted 23 May 2019

https://doi.org/10.31688/ABMU.2019.54.2.21

\section{Abstract}

Introduction. Thalassemias are the most common monogenic diseases. They are divided in two major categories: alpha - thalassemias (minor thalassemia), that do not have a special symptomatology and beta-thalassemias, which are a form of hereditary disease of hemoglobin (hemoglobinopathy), a severe form of anemia that requires treatment for life. In the case of major thalassemias, ketogenic analysis, the genetic defect occurs through deletions and point mutations of the gene that controls the synthesis of alpha or beta chains in messenger RNA at chromosome 11 level. It is an autosomal recessive disease. Homozygous patients with two beta-mutant genes have severe forms of diseases; heterozygous patients with a single beta-mutant allele have mild disease forms, but it is very important that they should be properly evaluated and diagnosed for genetic counseling. The objective was to describe dental abnormalities that occur in case of thalassemias. Materials and method. Two clinical cases of two patients aged 2 years and 12 years, diagnosed with beta-thalassemia and alpha-thalassemia, respectively, are presented.

\section{RÉSUMÉ}

Aspects cliniques bucco-dentaires chez les enfants thalassémiques

Introduction. Les thalassémies sont les maladies monogéniques les plus courantes. Elles sont divisées en deux grands groupes: les alpha-thalassémies (thalassémies mineures), qui ne présentent pas de symptomatologie particulière, et les bêta-thalassémies, qui sont une forme de maladie héréditaire de l'hémoglobine (hémoglobinopathie), une forme sévère d'anémie nécessitant un traitement pour la vie. Dans les cas de thalassémie majeure, analyse cétogène, le défaut génétique se produit par délétions et mutations ponctuelles du gène qui contrôle la synthèse des chaînes alpha ou bêta de l'ARN messager au niveau du chromosome 11. C'est une maladie autosomique récessive. Les patients homozygotes porteurs de deux gènes béta-mutants présentent des formes graves de la maladie - les patients hétérozygotes porteurs d'un seul allèle bêta-mutant présentent des formes bénignes, mais il est très 
Results. The disruptions that occurred, have resulted in physiognomic dysfunction, masticatory dysfunction, for which patients have requested dental care. The main problem is the optimization of the masticatory function, that can be solved at the age of the investigated patients, and will also solve the phonation disorder, followed by the supervision of the growth process and the intervention with other treatment solutions after the closure of the process.

Conclusions. The clinical picture of the patients in the study reproduces the data from the specialized literature: structural abnormalities causing severe evolving dental cavities. Regular follow-ups at the dental office in this case are very important but beneficial at the same time. In a proper feeding and nutritional state - against the background of severe chronic anemia, we need to avoid the onset of hemolytic crises caused by outbreaks of dental infection.

Keywords: thalassemia, dental abnormalities, masticatory dysfunction.

\section{INTRODUCTION}

Thalassemia is a disease characterized by the inability of erythroblasts to produce the $\beta$-chain of the normal hemoglobin structure ${ }^{1}$.

Thalassemia is considered the most common monogenic disease ${ }^{2}$. Beta-thalassemia occurs when a mutated gene is inherited from both parents, and Alpha-thalassemia is established when the child inherits a single mutation gene ${ }^{3}$. Beta-thalassemia is commonly found in the Mediterranean Sea basin (Greek "thalassa" means sea) ${ }^{4}$. It is an endemic disease in areas in the Middle East, India, or in tropical areas, but it can also be found in non-endemic areas (such as northern Europe) due to migration ${ }^{5}$. The explanation of increased frequency in the Mediterranean or tropical area is the defense mechanism of the human body against malaria, with heterozygotic being advantageous ${ }^{6}$.

Beta-thalassemias can be minor, moderate and severe. In the case of major thalassemia, genetic defects occur through deletions and point mutations of the gene that controls the synthesis of alpha or beta important qu'ils soient correctement évalués et diagnostiqués pour un conseil génétique.

L'objectif est de décrire les anomalies dentaires qui surviennent en cas de thalassémie.

Matériel et méthode. Deux cas cliniques de deux patients âgés respectivement de 2 et 12 ans, diagnostiqués avec une bêta-thalassémie et une alpha-thalassémie, sont présentés.

Résultats. Les perturbations survenues ont entraîné un dysfonctionnement physionomique, un dysfonctionnement masticatoire, pour lesquels les patients ont sollicité des soins dentaires. Le problème principal est l'optimisation de la fonction masticatoire qui peut être résolue à cet âge et résoudra le trouble de la phonation, suivie de la supervision du processus de croissance et de l'intervention d'autres solutions de traitement après la fermeture du processus. Conclusions. Le tableau clinique des patients de l'étude reproduit les données de la littérature de spécialité: anomalies structurelles provoquant des caries dentaires évolutives graves. Dans ce cas, un suivi régulier au cabinet dentaire est très important mais bénéfique en même temps. Dans un état nutritionnel et nutritionnel approprié - dans le contexte de l'anémie chronique sévère, nous devons éviter l'apparition de crises hémolytiques causées par des épidémies d'infection dentaire.

Mots-clés: thalassémie, anomalies dentaires, dysfonctionnement masticatoire.

chains in messenger RNA at the level of chromosome 11. It is an autosomal recessive disease. Homozygous patients with 2 betamutant genes have serious forms of disease - heterozygous patients with a single beta-mutant allele have mild disease forms, but it is very important that they are properly evaluated and diagnosed for genetic counseling?

Clinical picture - children with Cooley's anemia exhibit a height and weight hypotrophy. The characteristics are: facial dysmorphism with macrocranium, proeminent malar bones, hypertelorism, low root of the nose insertion, spleno-hepatomegaly, increased abdomen, heart failure, bone fragility. At the lower level of the face we encounter a voluminous jaw with prognatism, protrusion of the upper lip, hypertrophied gums, small teeth with implantation vices ${ }^{8}$.

The diagnosis is established by a rigorous anamnesis with heredo-collateral history. Paraclinic tests may detect chronic hemolytic anemia, reticulocytosis, increased hemoglobin percentage, increased iron uptake in the intestine. ${ }^{8}$.

The indicated treatment is customized for each patient, taking into account: medical history, age, 
health state and the recommendation of a healthy lifestyle with hygiene (including dental hygiene) rules strictly observed. The definitive treatment of the disease is allogenic bone marrow transplantation from the donor?.

The obJective was to describe dental abnormalities that occur in case of thalassemias.

\section{Material AND Method}

The cases that the authors dealt with are part of a retrospective epidemiological study of patients hospitalized for genetic diseases from whom it was chosen a group of patients with genetic diseases associated with oral manifestations.

The research was carried out using the admissions register and the medical records of the patients admitted (observation sheets, paraclinical analyses attached to the observation sheet). For the study of the medical papers, we have requested and received the approval of the hospital management and of the committee of ethics in research-development.

Two groups of patients admitted between 1990-1996 (group A) and 2010-2016 (group B) were included in the study. For each group, the initial eligibility criteria were:

- all patients with genetic diseases admitted to the hospital unit during the respective periods;

- diagnosis of genetic disease established and confirmed by cytogenetic analysis.

From all the patients admitted with genetic diseases, only patients with genetic diseases who also had oral manifestations were subsequently retained for the study. Regarding the patients with genetic diseases associated with oral manifestations, the parameters used for the study were the following:

- the age at which the genetic disease with oral manifestations was diagnosed;

- patient's sex;

- origin environment;

- rank of the child;

- type of oral lesion found.

For the study, a clinical examination of $52 \mathrm{pa}-$ tients diagnosed with a rascal genetic disease in the oral cavity was performed. The present study only dealt with bucco-dental aspects of children with thalassemia.

For the photographs of the patients, we asked for the confirmed consent of tutors, after their rights were presented. In the following we present two cases from our practice.

\section{Cases presentation}

\section{Case 1 - severe beta-thalassemia (Cooley)}

General data: male patient, aged 12 years, weight $27 \mathrm{~kg}$, urban environment.

Collateral hereditary history:

- Mother - 40 years of age, primi-gesta, primi-para, diagnosed at 30 years with minor thalassemia.

- Father - 40 year-old, diagnosed with minor thalassemia at 31 years.

- Observed pregnancy with late pregnancy pathological disorder.

Personal physiological history:

- Child born on term with $2400 \mathrm{~g}$, with good postnatal development

Personal medical history:

- Mother says he was pale „from birth“. At the age of one year and a half, he was hospitalized in a pediatric hospital in Bucharest, Romania, for an intercurrent upper respiratory infection.

Clinical examination - at this admission the following are noted: pale skin and pale mucous membranes, splenomegaly. The haemogram shows hypochromic anemia, and the smear reveals an increased number of reticulocytes and cells as a sign of targeting suggestive of thalassemia. Pathological hemoglobin electrophoresis was performed showing a high percentage of fetal hemoglobin and hemoglobin

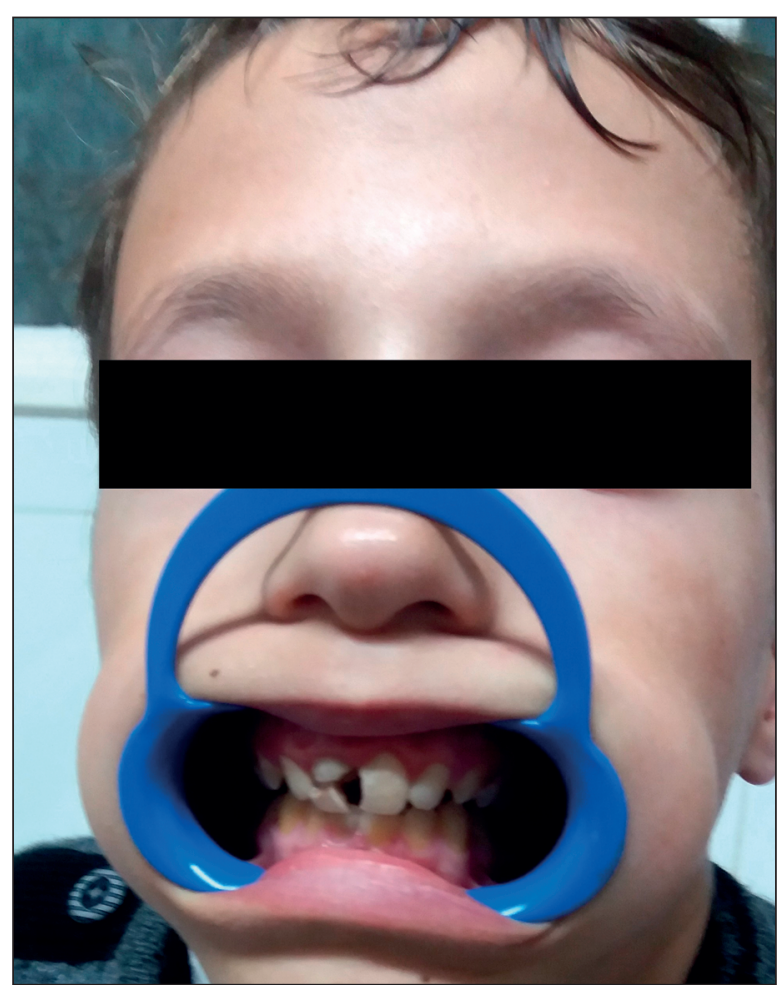

Figure 1. Facial and dental aspect of 12 years old thalassemic patient. 
A2. From the age of one year, the child returns to the pediatric-hematology department for substitution treatment - isogroup / isoRh blood transfusions.

General clinical examination (on admission from the time of study): marked pale skin and pale mucous membranes, facial dismophysis with mongoloid facies, prominent malar bones, "turiform" skull, hypertelorism, epicanthus and significant splenomegaly.

Exobuccal examination: a facies with pale tegument is shown (Fig. 1).

The middle floor highlights a small sized nasal pyramid. At the lower floor level, the mandible is retrograde. The functional examination reveals occlusal, structural and aesthetic disorders.

The patient has the following dental status:

\begin{tabular}{c|c|c|c|c|c|c|c|c|c|c|c}
$\mathrm{rr}$ & & & & & $\mathrm{mvpc}$ & $\mathrm{mpvc}$ & & & & & $\mathrm{rr}$ \\
\hline 16 & 15 & 14 & 13 & 12 & 11 & 21 & 22 & 23 & 24 & 25 & 26 \\
\hline 46 & 85 & 44 & 43 & 42 & 41 & 31 & 32 & 33 & 34 & 35 & 36 \\
\hline modc & $\operatorname{Rr}$ & & & & & & & & & &
\end{tabular}

Carious activity is significant in teeth of upper jaw. 11, 21 teeth with significant coronary distruction (mezio-vestibulary-palatinal caries mvpc). 11 also has a cavity in the form of a groove parallel to the incision edge. The enamel aspect shows areas of hypomineralization. Spots of enamel hypoplasia are also present at the level of 22, 23, 12, 13.

In the maxillary dental arch, which is prominent, there are also severe carious processes at the level of 16 and 26 - residual tooth root (rr).

At mandibular level, the teeth $(31,32,33,41,42$, 43) have a yellowish coloration. The lower right first molar has a medio-occlusal-distal caries (modc) and the second deciduous molar is still present on the dental arch as radicular rest ( $\mathrm{rr}$ ).

The crowns of 41 and 31 show a possible white demineralization.

The palatine vault is tall and ogival.

The gingival mucosa is inflamed and bleeding at the mere touch.

Oral hygiene is unsatisfactory.

\section{Case 2}

Minor beta-thalassemia - hemoglobinopathy, a monogenic disease - the heterozygous form.

General data: male, aged 5 years and one month, weight $10 \mathrm{~kg}$, urban environment

Collateral hereditary history:

- 22-year-old mother, apparently healthy, primiparous (under investigation at the time of study).
- 23-year-old father, apparently healthy (under investigation at the time of study).

- Monitored normal pregnancy, anemic mother during pregnancy.

Personal physiological history:

- First delivered in term, $3100 \mathrm{~g}$, good postnatal development.

Personal medical history:

- Admitted to a pediatric hospital in Bucharest for a digestive disorder, is found with hypochromic anemia (change in blood smear).

- Pathological hemoglobin electrophoresis, showing $12 \%$ A2 hemoglobin, was performed.

- Hematologic diagnosis shows minor beta-thalassemia.

Clinical general examination - visible pale skin and pale mucous membranes, discreet perioral nasal cyanosis. The feeling of the lower pole of the spleen at $2 \mathrm{~cm}$ under the rebord was confirmed by ultrasound investigation.

The facial examination reveals pale skin with mild peribuccal cyanosis. At the endobuccal level, implantation and shape abnormalities are observed.

The patient has temporary (decidual) dentition and has the following dental status:

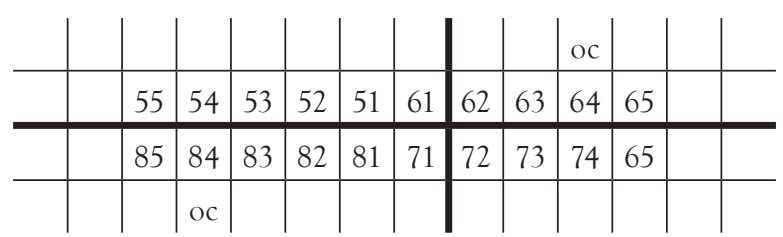

The teeth present microdontia (size abnormality) and position defects, with increased space in the upper incisive area; between the upper central incisors we noticed a $2 \mathrm{~mm}$ space - diastema (Fig. 2-a). In the area of the central and lateral lower incisors can be noticed bilaterally - a space of $2.5 \mathrm{~mm}$ in right dental hemiarcade and $1.5 \mathrm{~mm}$ respectively in the left side (Fig. 2-b).

Occlusal caries (oc) on upper first left decidual molar (64) and on lower first molar (84) can be observed.

A slight eruptive delay of the teeth on both dental arches can be noticed. Dental age is relevant for a 4 and half year-old child. Retromolar space is not enough developed.

The lips level is inverted with a thick and reversed lower lip.

\section{Results AND Discussion}

The disruptions that have occurred had resulted in physiognomic dysfunctions, for which patients have requested dental care. The main problem is the 

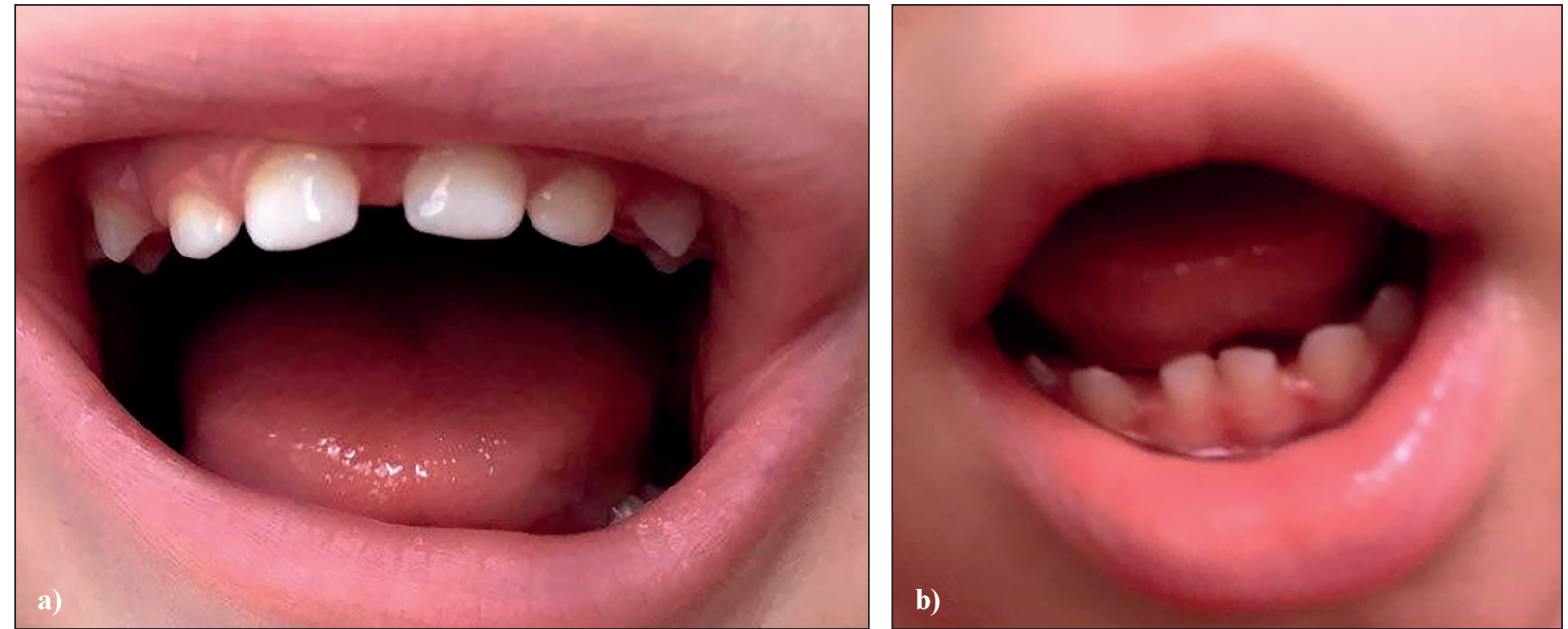

Figure 2. Thalassemic male, 5 years old, patient's upper arcade (a) and lower arcade (b) view.

optimization of the masticatory function that can be solved at this age, and it will also solve the phonetic disorder, followed by the supervision of the growth process and intervening with other treatment solutions after the closure of the process. The clinical picture of the patient in the study reproduces the data from the specialized literature: structural abnormalities causing severe evolving dental cavities. The clinical picture includes bulky volumetric jaw with prognatism, protrusion of the upper lip, hypertrophied gums, small teeth with implantation vices ${ }^{10}$. Regular check -ups at the dental office and monitoring the case are very important but beneficial at the same time. Appropriate nutrition is required when the patient experiences severe chronic anemia, but also to avoid the onset of haemolytic crises caused by outbreaks of dental infection. Dentists should consider, for this category of patients, that any surgical procedure will be under antibiotics and immediately after blood transfusion ${ }^{11}$.

In the case of minor thalassemia, the patient can live a normal life; the signs and symptoms include palpitations, fatigue and a family history with this pathology. Management of minor thalassemia is based on iron administration, as the risk of developing iron anemia is similar to that of the general population ${ }^{12}$. In patients with minor thalassemia it is very important to apply complete oral hygiene and adequate and personalized treatment of dental cavities, thus eliminating the outbreak of dental infection, which may adversely affect the evolution of the disease, accelerating the hemolysis of erythrocytes.

In severe forms, disease management is based on transfusions and on the administration of iron chelators. New research that leads to an in-depth knowledge of the molecular and pathogenic factors governing the pathogenic mechanisms of the disease has suggested ways to develop new therapeutic approaches addressing ineffective erythropoiesis, imbalances in iron metabolism and specific clinical complications ${ }^{13,14}$.

\section{Conclusions}

This diverse, multiple and potentially aggravating pathology, can be improved and the patient's life can also be improved through multi-disciplinary therapeutic strategies (pediatrician, hematologist, dentist, psychologist).

The dentist can provide prophylactic education for the children and their parents in order to enhance a good dental hygiene, dental follow-ups in the first signs of cavities or infection. The dentist can perform an early diagnosis and treat the diagnosed pathology.

Last, but not least, parents need to be part of this team, which, through awareness of this pathology and collaboration with the dentist, reduces the suffering and complications that may appear.

\section{Compliance with Ethics Requirements:}

„The authors declare no conflict of interest regarding this article"

"The authors declare that all the procedures and experiments of this study respect the ethical standards in the Helsinki Declaration of 1975, as revised in 2008(5), as well as the national law. Informed consent was obtained from all the patients included in the study"

"No funding for this study"

„All authors contributed equally to the study and take responsibility for the integrity of the data and the accuracy of the data analysis." 


\section{References}

1. Mut Popescu D. Hematologie clinica. Ed. Medicala Bucuresti, 1999, p. 86-89.

2. Zohreh R. Genetic epidemiology, hematological and clinical features of hemoglobinopathies in Iran. Biomed Res Int. 2013; 2013: 803487.

3. Weatherall DJ. Current trends in the diagnosis and man agement of haemoglobinopathies. Scand J Clin Lab Invest. 2007;67(1):1-2.

4. Cherry L, Calo C, Talmaci R, Perrin P, Gavrila L. $\beta$-Thalassemia haplotypes in Romania in the context of genetic mixing in the Mediterranean area. Hemoglobin. 2016; 40(2):85-96.

5. Birgens H, Ljung R. The thalassaemia syndromes. Scand J Clin Lab Invest. 2007;67(1):11-25.

6. Covic M, Stefanescu D, Sadovici I. Genetica medicala. Editia a II-a. Editura Polirom, Iasi, 2011.
7. Geormaneanu M. Patologie indusa prenatal. Editura Medicala, Bucuresti, 1978.

8. Puiu M, Skrypnyk C. Mic ghid de diagnostic în bolile rare. Editura Victor Babes, Timisoara, 2009.

9. Angelucci E, Pilo F, Coates TD. Transplantation in thalassemia: revisiting the Pesaro risk factors 25 years later. Am J Hematol. 2017;92(5):411-413.

10. Al-Wahadni AM, Taani DQ, Al-Omari MO. Dental diseases in subjects with beta-thalassemia major. Community Dent Oral Epidemiol. 2002; 30(6):418-22.

11. Helmi N, Bashir M, Shireen A, Ahmed IM. Thalassemia review: features, dental considerations and management. Electron Physician. 2017;9(3):4003-4008.

12. Choudhry VP. Thalassemia minor and major: current management. Indian J Pediatr. 2017;84(8):607-611.

13. Taher AT, Weatherall DJ, Cappellini MD. Thalassaemia. Lancet. 2018;13;391(10116):155-167.

14. Cappellini MD, Motta I. New therapeutic targets in transfusion-dependent and independent thalassemia. Hematology Am Soc Hematol Educ Program. 2017; 2017(1):278-283. 